\title{
AIR TEMPERATURE AND PRECIPITATION CHANGES IN THE KAFFIOYRA REGION (NW SPITSBERGEN) FROM 1975 TO 2010
}

\author{
RAJMUND PRZYBYLAK, MAREK KEJNA, ANDRZEJ ARAŹNY \\ Nicolaus Copernicus University, \\ Department of Climatology, Institute of Geography, \\ Gagarina 9, 87-100 Toruń, Poland \\ e-mail: rp11@umk.pl
}

\begin{abstract}
Air temperature and precipitation conditions in the Kaffiøyra region in the summer season ( $21^{\text {st }}$ July-31 $1^{\text {st }}$ August) for the period of 1975-2010 are described: 1) on the basis of data gathered in 18 expeditions during which meteorological measurements were done, and 2) on the basis of complete series of data combining both original and reconstructed data. The latter ones were obtained using data from Ny Ålesund meteorological station, which are strongly correlated with the data from Kaffiøyra. Seasonal statistics presented for air temperature and precipitation based on these two sets of data reveal only slight changes. Temperature parameters (daily mean, maximum and minimum) for summer in Kaffiøyra in the study period (1975-2010) show upward trends, which are, however, statistically significant only for the daily mean. On the other hand, precipitation totals in the study period reveal a downward trend, but not statistically significant. Such thermal-precipitation behaviour in the study part of Spitsbergen in general terms is similar to those in other parts of Spitsbergen.
\end{abstract}

KEY WORDS: Spitsbergen, Kaffiøyra, air temperature, precipitation, climate reconstruction. 


\section{INTRODUCTION}

The first Torun Polar Expedition to Kaffiøyra, located in the north-western part of Spitsbergen, was organized by the Institute of Geography, Nicolaus Copernicus University (NCU) and by the Institute of Geography and Spatial Organization, Polish Academy of Sciences in summer 1975. The last expedition took place in summer 2011. Within this time frame 19 expeditions altogether were organized with the participation of meteorologists and climatologists from the Department of Climatology NCU. Standard meteorological observations and measurements were made during all the expeditions near Polar Station of the Institute of Geography NCU (Kaffiøyra-Heggodden, see Figure 1, Photos 1 and 2). During almost all the expeditions a common period of observations included a time frame from $21^{\text {st }} \mathrm{July}$ to $31^{\text {st }}$ August. Therefore, the analysis presented in the paper is limited to this period.

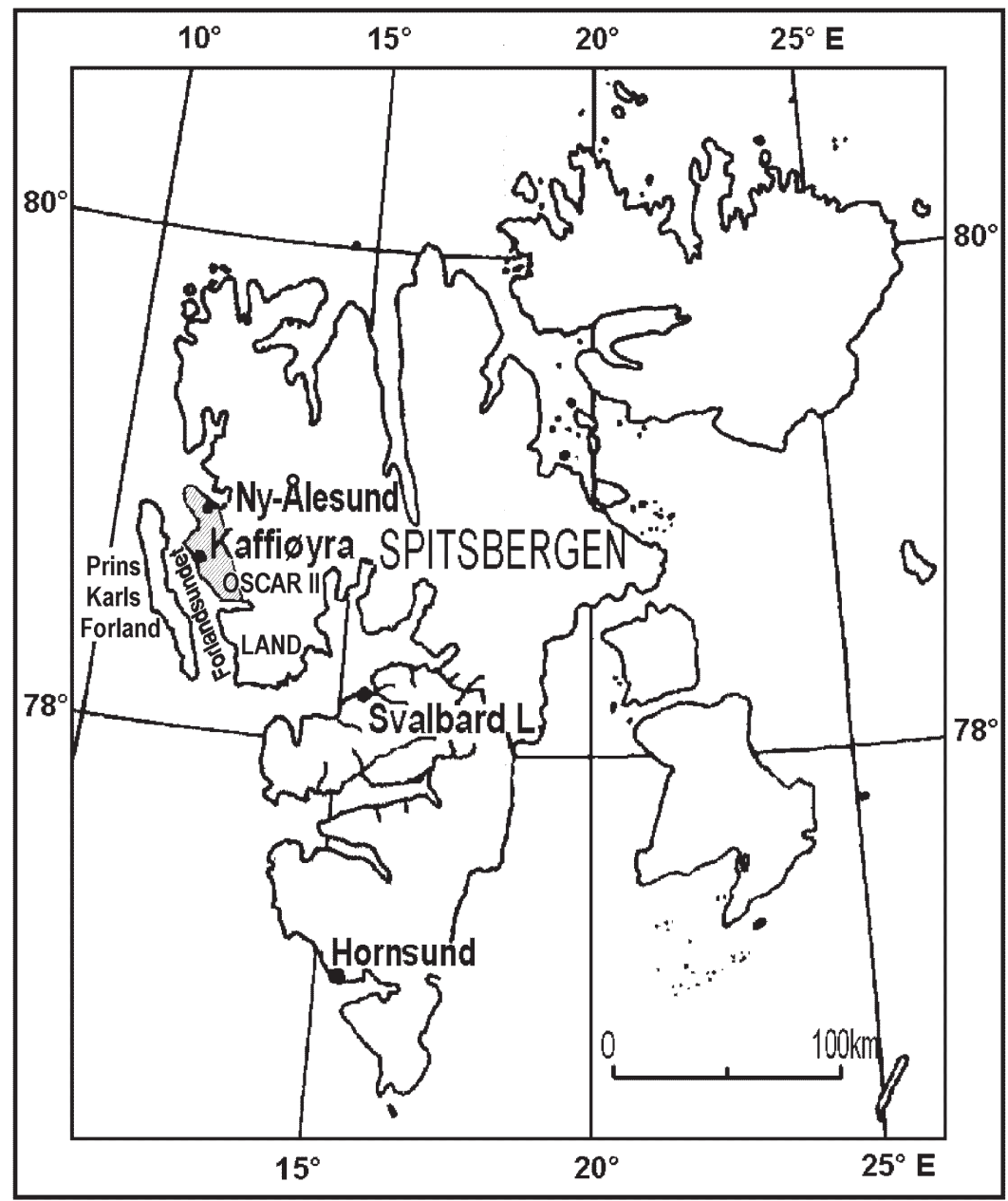

Figure 1. Map showing the location of the study area 


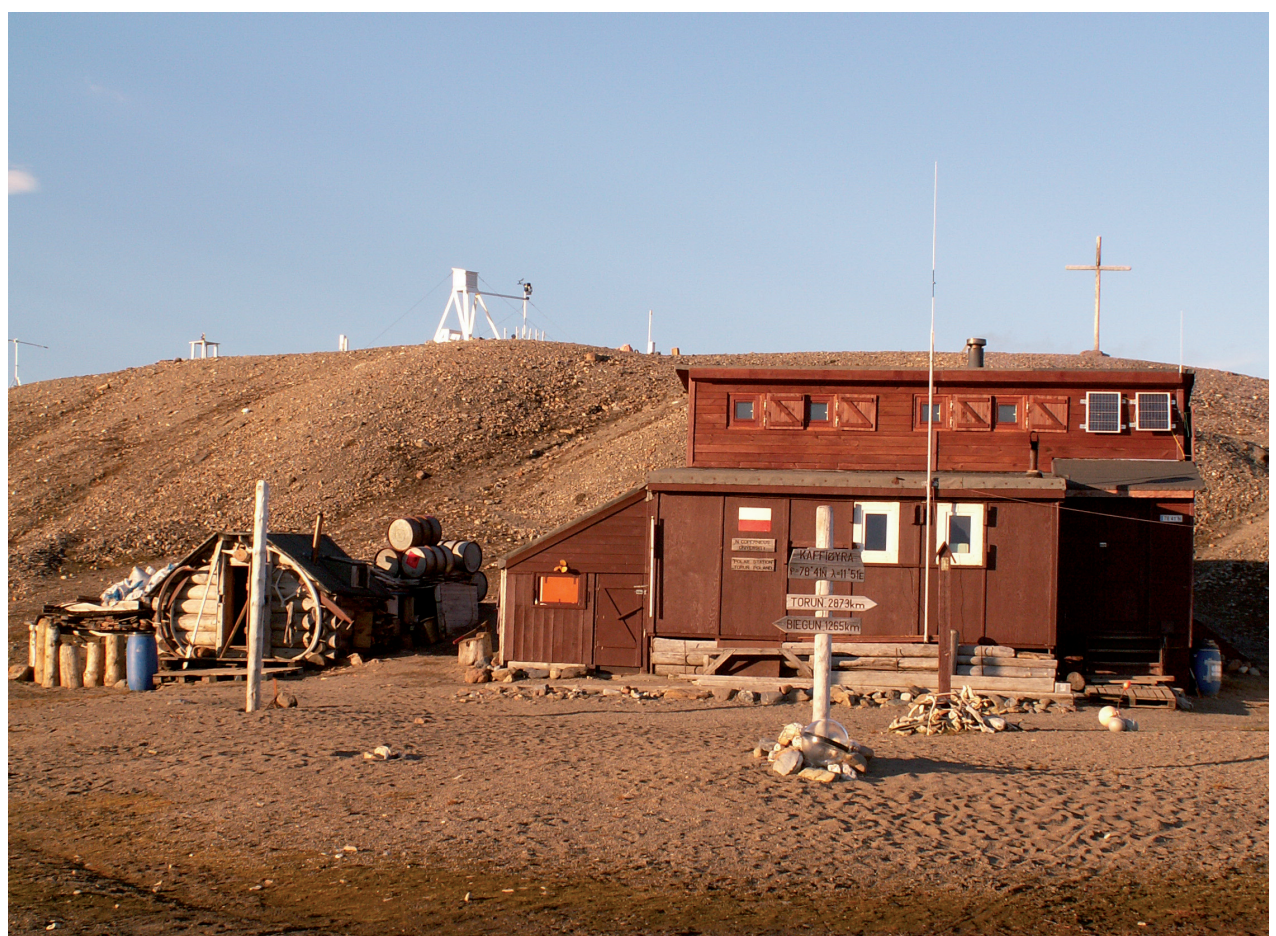

Photo 1. Nicolaus Copernicus University Polar Station, Kaffiøyra, Spitsbergen (Photo A. Araźny 2010)

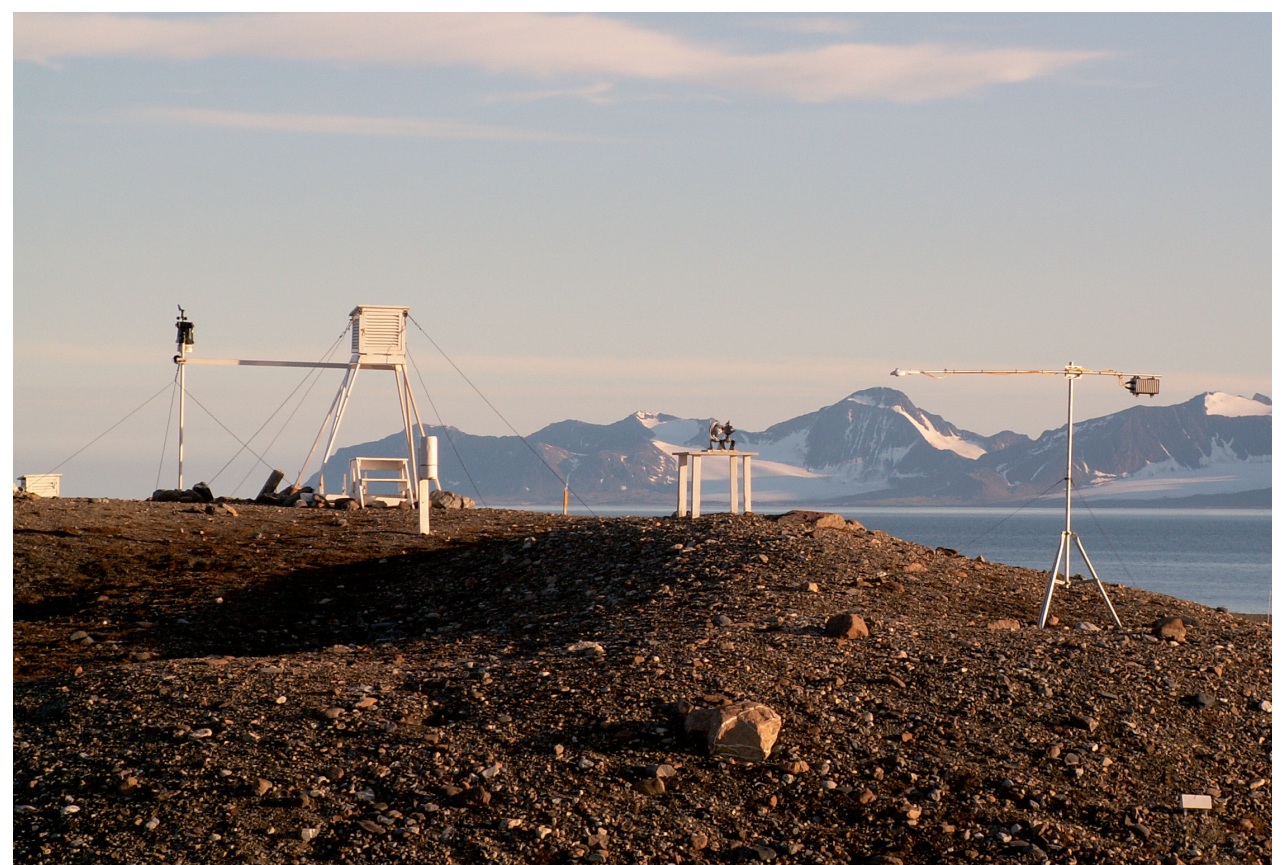

Photo 2. Meteorological station Kaffiøyra-Heggødden, NW Spitsbergen (Photo A. Araźny 2010) 
Untill now there have been more than 80 publications published based on meteorological data gathered during all 19 Toruń Polar Expeditions to Spitsbergen. Weather descriptions made during the expeditions, including also daily data, are presented in the following papers: Leszkiewicz 1977; Wójcik 1982; Wójcik, Marciniak 1983; Marciniak, Przybylak 1983, 1991; Wójcik et al. 1991, Wójcik, Przybylak 1991; Kejna, Dzieniszewski 1993; Marciniak et al. 1993; Kejna 2002; Araźny 1999, 2002; Przybylak, Szczeblewska 2002, Kejna, Maszewski 2007; Przybylak, Araźny 2007; Maszewski, Wyszyński 2008; Jankowska, Kejna 2010.

All meteorological data from observations made during the expeditions organized from 1975 to 1989 are published in extenso in a publication written by Wójcik et al. (1997). However, untill now climate changes in this area have not been analysed. The reason was too short and not continuous series of observations. Recently, however, we estimate that there is enough data for a reliable reconstruction of the gaps in them with the use of data from the neighbouring station, i.e. from $\mathrm{Ny}$ Alesund, located about $30 \mathrm{~km}$ to the north from our station. In the present paper two main meteorological variables (air temperature and precipitation) are reconstructed and analysed. The rest of meteorological variables will be analysed in separate papers.

The main aim of the present paper is to describe temperature and precipitation conditions in the study region for the whole period (1975-2010) and to estimate their changes. It is very important if the changes of the analysed variables, and in particular air temperature, are in line with changes observed for the globe and the Arctic as a whole. It must be stressed here that the period covered by the meteorological observations in Kaffiøyra coincides with the second phase of contemporary global warming, which started in the mid-1970s.

\section{DATA AND METHODS}

Source data used in the present paper include fixed hours temperature data $\left(1: 00,7: 00,13: 00\right.$, and 19:00 CET), as well as the maximum $\left(\mathrm{T}_{\max }\right)$ and minimum $\left(\mathrm{T}_{\min }\right)$ daily temperature and daily totals for precipitation from Nicolaus Copernicus University Polar Station. Temperature and precipitation measurements throughout all the study periods were done in the same site, using the same kind of instruments, i.e. mercury thermometers and Hellmann's ombrometer, and the same methodology. As a result, the gathered series of data, both of temperature and precipitation, are homogeneous.

Mean daily temperature $\left(\mathrm{T}_{\mathrm{i}}\right)$ was calculated as a simple arithmetic mean of temperature measured during four times of observations mentioned above. Daily data were used to calculate seasonal ( $21^{\text {st }}$ July- $31^{\text {st }}$ August) statistics. Both air temperature and precipitation gaps existing in the data from Kaffiøyra were 
completed using data from the nearest (distance $30 \mathrm{~km}$ ) Norwegian meteorological station working in Ny Ålesund (Fig. 1). For this purpose a correlation method was applied. For completed series, trends were computed using the regression equation: $y=a x+b$, where $y$ is air temperature or precipitation, and $x$ is the time. For the estimation of statistical significance of the calculated trends Students' $t$ test was used.

\section{RESULTS}

\section{AIR TEMPERATURE AND PRECIPITATION FROM OBSERVATIONS}

\section{Air temperature}

Weather conditions during all Torun Polar Expeditions to Kaffiøyra (Spitsbergen) are presented in Table 1. Generally, in Kaffiøyra, as it can be seen from the Table, mean wind speed, cloudiness and relative humidity are very high, while sunshine duration is limited. Mean air temperature in the common period of observations ( $21^{\text {st }} \mathrm{July}-31^{\text {st }}$ August, hereafter described as summer season) was $4.8^{\circ} \mathrm{C}$. The warmest summer season $\left(6.3^{\circ} \mathrm{C}\right)$ occurred in 1998 , while the coldest one $\left(3.3^{\circ} \mathrm{C}\right)$ in 1982 (Tab. 1, Fig. 2). Also mean Tmax and mean Tmin were the highest and the lowest, respectively, in the mentioned seasons. The absolute minimum temperature $\left(-4.2^{\circ} \mathrm{C}\right)$ noted in the study period occurred in the coldest season, while the absolute maximum observed in the warmest season was the third highest value. The highest air temperature $\left(18.9^{\circ} \mathrm{C}\right)$ occurred in Kaffiøyra on $15^{\text {th }}$ August 1979. The analysis of the attached documentation allows to state that after mid 1990s air temperature in the Kaffiøyra was definitely higher than in the earlier period. This is in line with other observations made for Spitsbergen (e.g. Nordli 2010) and for the Arctic (Przybylak 2007).

Mean daily air temperature in the study period very rarely dropped below $0^{\circ} \mathrm{C}$ (Fig. 3). Such situation occurred only in two seasons (1982 and 1989) at the end of August. The highest calculated mean daily air temperature $\left(13.9^{\circ} \mathrm{C}\right)$ was noted on $16^{\text {th }}$ August 1979 , while the lowest one $\left(-1.8^{\circ} \mathrm{C}\right)$ on $31^{\text {st }}$ August 1982 . The range of $\mathrm{T}_{\mathrm{i}}$ on each day of the summer season oscillates generally from 6 to $8^{\circ} \mathrm{C}$, so it is quite large. Looking at all the courses of $T_{i}$ and its mean course from all the expeditions, it is well seen that from the end of July a downward trend is observed. One singularity in the course of $T_{i}$ in the summer season is evident at the turn of July and August. During almost each expedition a marked coolness in temperature was observed at this time (Fig. 3). Very often even a snowfall was observed at this time, in particular in mountain areas. 
Table 1. Mean values of the chosen meteorological elements in Kaffiøyra-Heggodden station in the summer seasons ( $21^{\text {st }}$ July-31 $31^{\text {st }}$ August $), 1975-2010$

\begin{tabular}{|c|c|c|c|c|c|c|c|c|c|c|c|}
\hline \multirow{2}{*}{ Year } & \multirow{2}{*}{$\begin{array}{c}\mathrm{V} \\
{[\mathrm{m} / \mathrm{s}]}\end{array}$} & \multirow{2}{*}{$\begin{array}{c}\mathrm{C} \\
{[0-10]}\end{array}$} & \multirow{2}{*}{$\begin{array}{l}\text { SS } \\
{[\mathrm{h}]}\end{array}$} & $\mathrm{T}_{\text {max abs }}$ & $\mathrm{T}_{\max }$ & $\mathrm{T}_{\mathrm{i}}$ & $\mathrm{T}_{\min }$ & $\mathrm{T}_{\min \text { abs }}$ & DTR & \multirow{2}{*}{$\begin{array}{c}\mathrm{f} \\
{[\%]}\end{array}$} & \multirow{2}{*}{$\begin{array}{c}\mathrm{P} \\
{[\mathrm{mm}]}\end{array}$} \\
\hline & & & & \multicolumn{6}{|c|}{$\left[{ }^{\circ} \mathrm{C}\right]$} & & \\
\hline 1975 & 4.3 & 8.7 & 112.9 & 11.5 & 6.7 & 4.9 & 3.3 & 1.4 & 3.4 & 90 & 66.5 \\
\hline $1977^{*}$ & 3.2 & 8.7 & 147.6 & 13.5 & 7.0 & 5.0 & 3.5 & 0.6 & 3.5 & 89 & 44.4 \\
\hline 1978 & 4.6 & 8.8 & 119.9 & 10.0 & 6.3 & 4.7 & 3.1 & 0.7 & 3.2 & 89 & 44.2 \\
\hline 1979 & 5.0 & 7.3 & 281.9 & 18.9 & 6.6 & 4.5 & 2.5 & -0.5 & 4.1 & 89 & 17.7 \\
\hline 1980 & 5.5 & 9.1 & 90.9 & 12.5 & 5.6 & 4.1 & 2.6 & -0.8 & 3.0 & 88 & 108.0 \\
\hline 1982 & 4.2 & 8.8 & 91.3 & 10.4 & 4.8 & 3.3 & 1.8 & -4.2 & 3.0 & 88 & 54.5 \\
\hline 1985 & 3.2 & 7.2 & 309.5 & 16.0 & 6.9 & 5.4 & 4.0 & 0.9 & 2.9 & 89 & 13.9 \\
\hline 1989 & 5.0 & 8.3 & 203.0 & 11.5 & 5.5 & 4.0 & 2.7 & -3.6 & 2.8 & 90 & 27.0 \\
\hline 1997 & $5.4 * *$ & 8.4 & 165.0 & 10.8 & 5.4 & 4.2 & 2.7 & -0.2 & 2.7 & 90 & 122.5 \\
\hline 1998 & 4.0 & 9.1 & 93.5 & 14.0 & 7.6 & 6.3 & 5.0 & 1.8 & 2.6 & 91 & 16.0 \\
\hline 1999 & 3.8 & 8.9 & 150.1 & 10.3 & 6.4 & 4.9 & 3.5 & 0.0 & 2.9 & 85 & 58.4 \\
\hline 2000 & 4.6 & 7.2 & 213.3 & 8.8 & 5.9 & 3.9 & 2.2 & -3.6 & 3.7 & 88 & 29.1 \\
\hline 2005 & 3.8 & 9.1 & 149.4 & 12.1 & 7.5 & 5.8 & 4.1 & 1.4 & 3.4 & 87 & 49.9 \\
\hline 2006 & 5.0 & 8.3 & 158.0 & 11.9 & 7.0 & 5.2 & 3.9 & 1.0 & 3.1 & 91 & 25.1 \\
\hline 2007 & 3.7 & 8.7 & 132.0 & 13.9 & 7.4 & 5.5 & 4.0 & -1.3 & 3.6 & 85 & 12.3 \\
\hline 2008 & 5.4 & 8.9 & 131.7 & 12.4 & 6.1 & 4.5 & 2.9 & -0.8 & 3.2 & 88 & 22.2 \\
\hline 2009 & 3.1 & 7.9 & 220.0 & 13.0 & 7.6 & 6.1 & 4.1 & 0.9 & 3.5 & 87 & 13.0 \\
\hline 2010 & 5.8 & 8.2 & 219.9 & 10.8 & 6.1 & 4.1 & 2.7 & -0.6 & 3.4 & 87 & 8.5 \\
\hline $\begin{array}{c}1975- \\
2010\end{array}$ & 4.4 & 8.4 & 166.1 & 18.9 & 6.4 & 4.8 & 3.3 & -4.2 & 3.2 & 89 & 40.7 \\
\hline
\end{tabular}

Explanations: * - 21.07-28.08; ** - 28.07-31.08; V - wind velocity; C - cloudiness; $\mathrm{SS}$ - air sunshine duration; $\mathrm{T}_{\max \text { abs }}-$ absolute maximum air temperature; $\mathrm{T}_{\max }-$ maximum daily air temperature; $T_{i}-$ mean daily air temperature; $T_{\min }-$ minimum daily air temperature, $T_{\text {min abs }}-$ absolute minimum air temperature; DTR - mean diurnal air temperature range; $\mathrm{f}$ - relative air humidity; $\mathrm{P}-$ sum of precipitation.

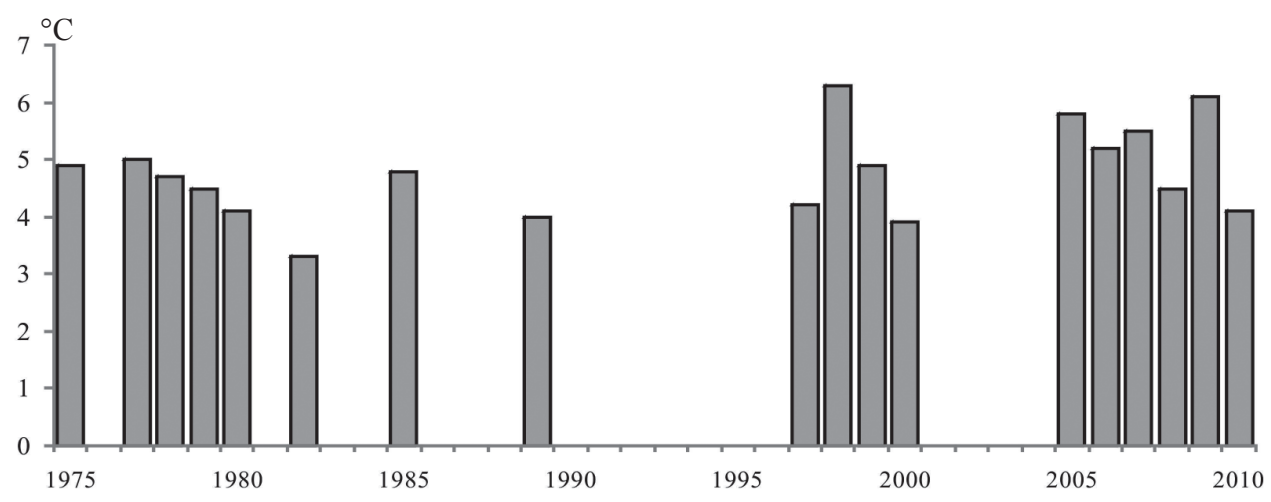

Figure 2. Mean values of summer ( $21^{\text {st }}$ July-31 $1^{\text {st }}$ August) air temperature in Kaffiøyra-Heggodden station, 1975-2010 


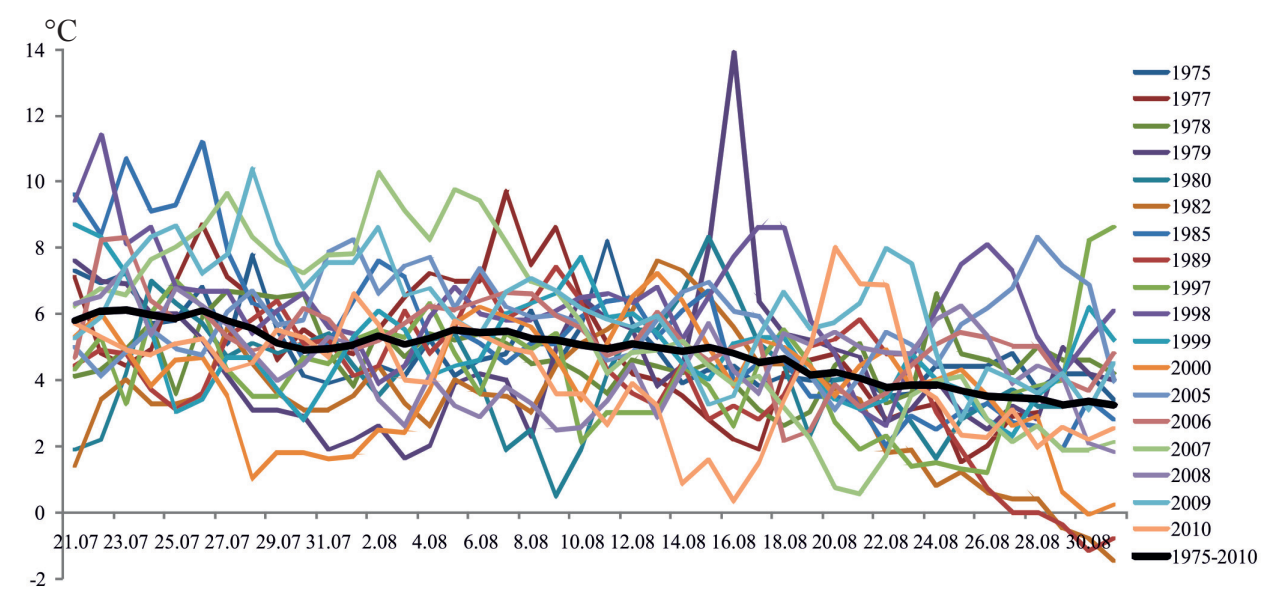

Figure 3. Courses of mean daily air temperature in Kaffiøyra-Heggodden (KH) station in the summer seasons ( $21^{\text {st }}$ July-31 $1^{\text {st }}$ August $), 1975-2010$

\section{Precipitation}

The average precipitation total in Kaffiøyra in the summer season calculated from 18 expeditions was equal to $40.7 \mathrm{~mm}$. Season-to-season changes in precipitation are very high (Tab. 1, Fig. 4). Suffice it to say that the wettest season (1997) saw $122.5 \mathrm{~mm}$, while the driest one (2010) only $8.5 \mathrm{~mm}$. Very wet seasons were observed also in $1980(108 \mathrm{~mm})$ and $1975(66.5 \mathrm{~mm})$. In Kaffiøyra dry summers are more common than wet ones. Seasonal precipitation totals below $20 \mathrm{~mm}$ were noted in 6 years: 1997, 2007, 2009, 1985, 1998, and 1979. Definitely more of the driest seasons are noted in the second part of the study period than in the first. Such behavior, i.e. increasing warming and decreasing precipitation observed in Kaffiøyra, is not in line with climate models projections, which suggest that in the warmer climate more precipitation should also occur, but it is in line with previous findings of Przybylak (2002, 2003).

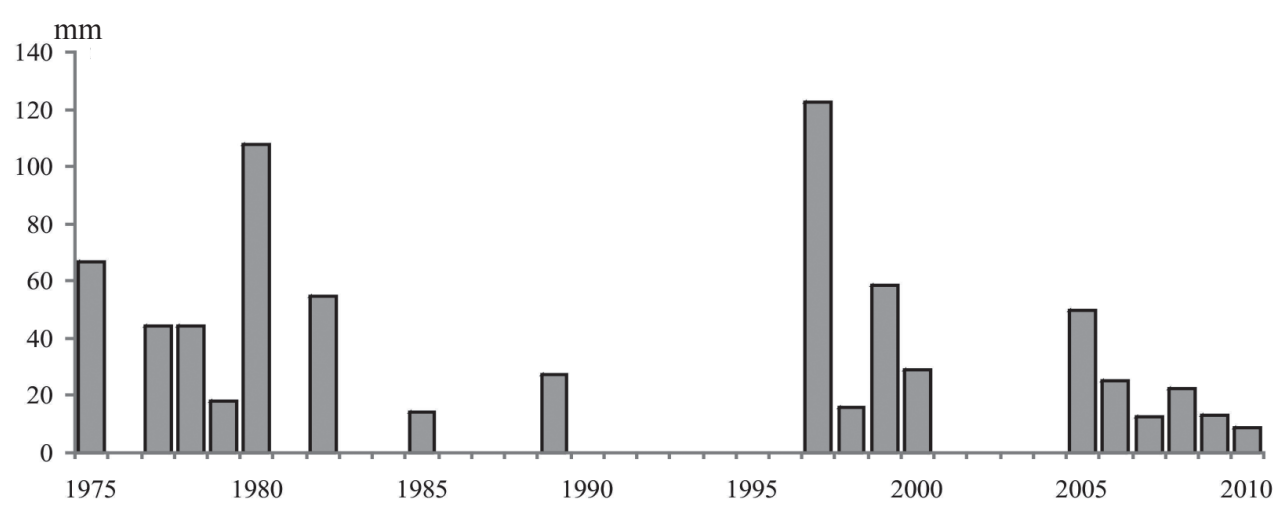

Figure 4. Totals of summer ( $21^{\text {st }}$ July-31 $1^{\text {st }}$ August) sum of precipitation in Kaffiøyra-Heggodden (KH) station, 1975-2010 


\section{AIR TEMPERATURE AND PRECIPITATION RECONSTRUCTIONS}

Comparison of temperature and precipitation totals for all the seasons when observations were made in Kaffiøyra are shown in Table 2. Average seasonal $T_{i}$ and $\mathrm{T}_{\text {min }}$ are lower in Ny Ålesund than in Kaffiøyra by about 0.3 and $0.4^{\circ} \mathrm{C}$, respectively. On the other hand, Tmax was on average slightly higher (by $0.1^{\circ} \mathrm{C}$ ). Both absolute values of temperature $\left(\mathrm{T}_{\max }\right.$ and $\mathrm{T}_{\text {min }}$ ) were lower than in Kaffiøyra. Mean precipitation totals in Kaffiøyra (40.7 mm) were higher than in Ny Ålesund $(37.9 \mathrm{~mm})$. In conclusion, we can say that both thermal and precipitation conditions in the compared sites are very similar (Przybylak, Araźny 2006). To check how strong these relationships are, correlation coefficients were calculated, using both daily and seasonal values for air temperature parameters and only seasonal values for precipitation.

Figure 5 shows relationships between daily temperatures $\left(\mathrm{T}_{\mathrm{i}}, \mathrm{T}_{\max }\right.$ and $\left.\mathrm{T}_{\min }\right)$ in Ny Ålesund and Kaffiøyra. Correlation coefficients (r) are very high for all temperature parameters, but the highest one is for $T_{i}(0.89)$. The same value of the correlation coefficient was obtained for $\mathrm{T}_{\mathrm{i}}$ using seasonal data, while slightly different coefficients were calculated for $\mathrm{T}_{\max }$ and $\mathrm{T}_{\min }$ (compare Figs 5 and 6). For $T_{\min }$ seasonal values are better correlated than daily values, while for $T_{\max }$ the opposite situation is noted.

Table 2. Mean values of air temperature $(\mathrm{T})$ and totals of precipitation $(\mathrm{P})$ in Kaffiøyra-Heggodden

(KH) and NyÅlesund (NA) stations for the summer seasons (21 $1^{\text {st }}$ July-31 $1^{\text {st }}$ August) $1975-2010$ calculated on the basis of observational data

\begin{tabular}{|c|c|c|c|c|c|c|c|c|c|c|c|c|}
\hline \multirow{2}{*}{ Year } & \multicolumn{2}{|c|}{$\mathrm{T}_{\mathrm{i}}\left[{ }^{\mathrm{o}} \mathrm{C}\right]$} & \multicolumn{2}{|c|}{$\mathrm{T}_{\min }\left[{ }^{\circ} \mathrm{C}\right]$} & \multicolumn{2}{|c|}{$\mathrm{T}_{\text {min abs }}\left[{ }^{\circ} \mathrm{C}\right]$} & \multicolumn{2}{|c|}{$\mathrm{T}_{\max }\left[{ }^{\circ} \mathrm{C}\right]$} & \multicolumn{2}{|c|}{$\mathrm{T}_{\max \text { abs }}\left[{ }^{\circ} \mathrm{C}\right]$} & \multicolumn{2}{|c|}{$\mathrm{P}[\mathrm{mm}]$} \\
\hline & NA & $\mathrm{KH}$ & NA & $\mathrm{KH}$ & NA & $\mathrm{KH}$ & NA & $\mathrm{KH}$ & NA & $\mathrm{KH}$ & NA & $\mathrm{KH}$ \\
\hline 1975 & 4.8 & 4.9 & 3.2 & 3.3 & 0 & 1.4 & 6.2 & 6.7 & 11.5 & 11.5 & 66.6 & 66.5 \\
\hline 1977 & 4.4 & 5.0 & 2.8 & 3.5 & & 0.6 & & 7.0 & & 13.5 & & 44.4 \\
\hline 1978 & 4.8 & 4.7 & 2.9 & 3.1 & -0 & 0.7 & 6.7 & 6.3 & 9 & 10.0 & 13.1 & 44.2 \\
\hline 1979 & 4.7 & 4.5 & 2.9 & 2.5 & -1 & -0.5 & 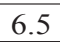 & 6.6 & 12 & 8.9 & 15.7 & 7.7 \\
\hline 1980 & 4.3 & 4.1 & 2.7 & 2.6 & -1.6 & -0.8 & 6.0 & 5.6 & 12.1 & 12.5 & 159.6 & 108.0 \\
\hline 1982 & 3.4 & 3.3 & 2.1 & 1.8 & -5.5 & -4.2 & 4.8 & 4.8 & 8.9 & 10.4 & 54.6 & 54.5 \\
\hline 1985 & 4.5 & 5.4 & 3.0 & 4.0 & -1. & 0.9 & 6.7 & 6.9 & 13.5 & 16.0 & 20.0 & 13.9 \\
\hline 1989 & 3.7 & 4.0 & 2.3 & 2.7 & -3 & -3.6 & 5.8 & 5.5 & 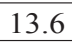 & 11.5 & 4 & 27.0 \\
\hline 1997 & 4.4 & 4.2 & 2.6 & 2.7 & -2 . & -0.2 & 6. & 5.4 & 18 & 10.8 & 57.8 & 122.5 \\
\hline 1998 & 6.2 & 6.3 & 4.4 & 5.0 & 0.7 & 1.8 & 8.9 & 7.6 & 14.5 & 14.0 & 9.4 & 16.0 \\
\hline 1999 & 4.4 & 4.9 & 2.7 & 3.5 & -1.3 & 0.0 & 6.2 & 6.4 & 9.9 & 10.3 & 42.8 & 58.4 \\
\hline 2000 & 3.5 & 3.9 & 1.8 & 2.2 & -3.3 & -3.6 & 5.6 & 5.9 & 10.1 & 8.8 & 2.7 & 29.1 \\
\hline 2005 & 5.3 & 5.8 & 3. & 4.1 & 0.6 & 1.4 & 7.3 & 7.5 & & 12.1 & 6 & 49.9 \\
\hline 2006 & 5.1 & 5. & 3.8 & 3.9 & -0. & 1.0 & 6.8 & 7.0 & 10 & 11.9 & 2 & 25.1 \\
\hline 2007 & 5.1 & 5.5 & 3.5 & 4.0 & -1.4 & -1.3 & 7.2 & 7.4 & 14.1 & 13.9 & 32.2 & 12.3 \\
\hline 2008 & 4.1 & 4.5 & 2.5 & 2.9 & -0.4 & -0.8 & 6.2 & 6.1 & 9.9 & 12.4 & 20.7 & 22.2 \\
\hline 2009 & 5.0 & 6.1 & 3.1 & 4.1 & -1.2 & 0.9 & 7.1 & 7.6 & 13.6 & 13.0 & 39.4 & 13.0 \\
\hline 201 & 3.9 & 4.1 & 2.0 & 2.7 & -1.2 & -0.6 & 6.0 & 6.1 & 10.6 & 10.8 & 13.3 & 8.5 \\
\hline $1975-2010$ & 4.5 & 4.8 & 2.9 & 3.3 & -1.3 & -4.2 & 6.5 & 6.4 & 18.3 & 18.9 & 37.9 & 40.7 \\
\hline
\end{tabular}

For the meaning of abbreviations see Table 1. 
Both spatial and temporal variability of precipitation are the greatest of all meteorological variables. As a result, the correlation coefficient between seasonal totals of precipitation in Ny Ålesund and Kaffiøyra is lower than for air temperature, but still very high $(\mathrm{r}=0.72)$ (Fig. 7). The documented very strong thermal-precipitation relationships between Ny Ålesund and Kaffiøyra allow us to reconstruct gaps existing in the analysed data series from Kaffiøyra using data from

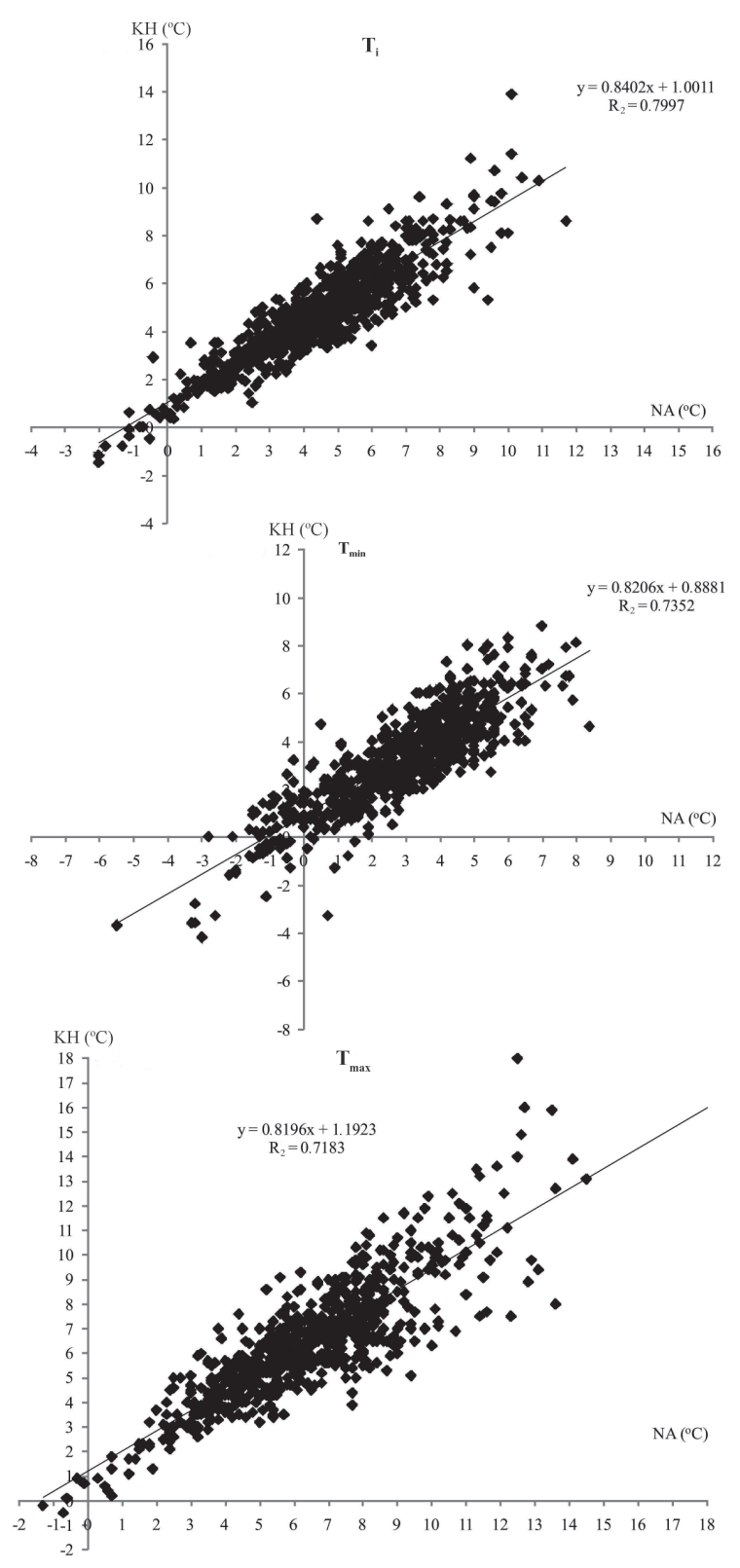

Figure 5. Relationships between daily air of temperatures $\left(T_{i}, T_{\min }\right.$ and $\left.T_{\max }\right)$ in Ny Ålesund (NY) and

Kaffiøyra-Heggodden (KH) stations in the summer seasons

(21 $1^{\text {st }}$ July-31 $1^{\text {st }}$ August), 1975-2010 
Figure 6. Relationships between mean seasonal ( $21^{\text {st }}$ July$31^{\text {st }}$ August) air temperature $\left(\mathrm{T}_{\mathrm{i}}, \mathrm{T}_{\text {min }}\right.$ and $\left.\mathrm{T}_{\max }\right)$ in Ny Ålesund (NA) and Kaffiøyra-Heggodden (KH) stations, 1975-2010

Figure 7. Relationships between seasonal ( $21^{\text {st }}$ July- $31^{\text {st }}$ August) totals of precipitation in $\mathrm{Ny}$ Ålesund (NA) and KaffiøyraHeggodden (KH) stations,

$$
\text { 1975-2010 }
$$
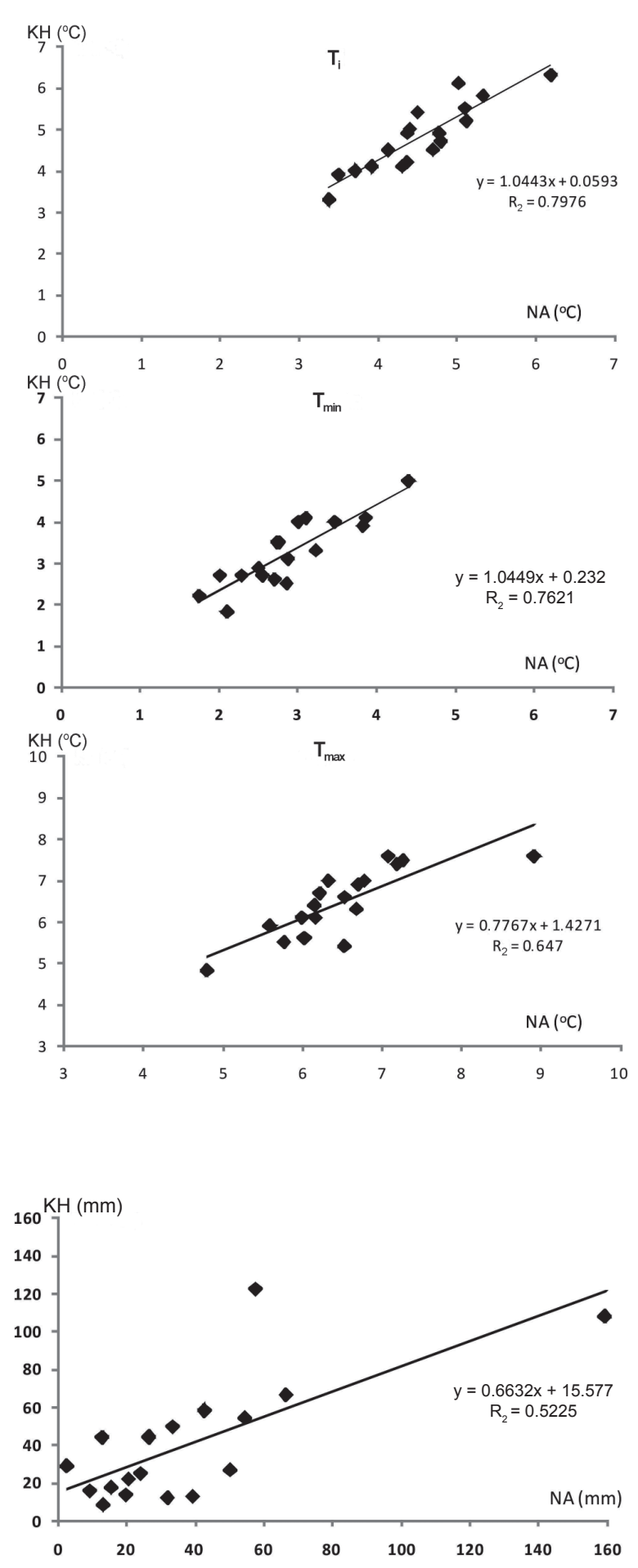
Table 3. Original and reconstructed mean values of air temperature $\left(\mathrm{T}_{\mathrm{i}}, \mathrm{T}_{\min }, \mathrm{T}_{\max }\right)$ and totals of precipitation (P) in the Kaffiøyra-Heggodden (KH) and NyÅlesund (NA) stations in the summer seasons ( $21^{\text {st }}$ July-31 ${ }^{\text {st }}$ August), 1975-2010

\begin{tabular}{|c|c|c|c|c|c|c|c|c|}
\hline \multirow{2}{*}{ Year } & \multicolumn{2}{|c|}{$\mathrm{T}_{\mathrm{i}}\left[{ }^{\mathrm{o}} \mathrm{C}\right]$} & \multicolumn{2}{|c|}{$\mathrm{T}_{\min }\left[{ }^{\mathrm{o}} \mathrm{C}\right]$} & \multicolumn{2}{|c|}{$\mathrm{T}_{\max }\left[{ }^{\mathrm{o}} \mathrm{C}\right]$} & \multicolumn{2}{|c|}{$\mathrm{P}[\mathrm{mm}]$} \\
\hline & NA & $\mathrm{KH}$ & NA & $\mathrm{KH}$ & NA & $\mathrm{KH}$ & NA & $\mathrm{KH}$ \\
\hline 1975 & 4.8 & 4.9 & 3.2 & 3.3 & 6.2 & 6.7 & 66.6 & 66.5 \\
\hline 1976 & 4.4 & 4.7 & 2.6 & 3.0 & 6.2 & 6.2 & 122.3 & 96.7 \\
\hline 1977 & 4.4 & 5.0 & 2.8 & 3.5 & 6.3 & 7.0 & 26.7 & 44.4 \\
\hline 1978 & 4.8 & 4.7 & 2.9 & 3.1 & 6.7 & 6.3 & 13.1 & 44.2 \\
\hline 1979 & 4.7 & 4.5 & 2.9 & 2.5 & 6.5 & 6.6 & 15.7 & 17.7 \\
\hline 1980 & 4.3 & 4.1 & 2.7 & 2.6 & 6.0 & 5.6 & 159.6 & 108.0 \\
\hline 1981 & 5.0 & 5.3 & 3.6 & 4.0 & 6.8 & 6.6 & 69.1 & 61.4 \\
\hline 1982 & 3.4 & 3.3 & 2.1 & 1.8 & 4.8 & 4.8 & 54.6 & 54.5 \\
\hline 1983 & 3.9 & 4.1 & 2.6 & 2.9 & 5.7 & 5.8 & 29.0 & 34.8 \\
\hline 1984 & 5.0 & 5.3 & 3.6 & 3.9 & 7.3 & 7.1 & 28.9 & 34.7 \\
\hline 1985 & 4.5 & 4.8 & 3.0 & 3.4 & 6.7 & 6.6 & 20.0 & 28.8 \\
\hline 1986 & 4.7 & 5.4 & 3.6 & 4.0 & 6.5 & 6.9 & 54.1 & 13.9 \\
\hline 1987 & 3.4 & 3.6 & 2.3 & 2.6 & 5.7 & 5.8 & 46.7 & 46.5 \\
\hline 1988 & 5.1 & 5.4 & 3.7 & 4.1 & 7.5 & 7.3 & 37.9 & 40.7 \\
\hline 1989 & 3.7 & 4.0 & 2.3 & 2.7 & 5.8 & 5.5 & 50.4 & 27.0 \\
\hline 1990 & 4.7 & 5.0 & 2.9 & 3.3 & 6.9 & 6.8 & 31.5 & 36.5 \\
\hline 1991 & 5.2 & 5.5 & 3.6 & 4.0 & 7.1 & 6.9 & 51.9 & 50.0 \\
\hline 1992 & 4.1 & 4.3 & 2.4 & 2.8 & 5.9 & 6.0 & 42.7 & 43.9 \\
\hline 1993 & 5.1 & 5.4 & 3.5 & 3.9 & 7.3 & 7.1 & 69.8 & 61.9 \\
\hline 1994 & 3.3 & 3.5 & 1.7 & 2.0 & 5.1 & 5.4 & 62.9 & $\mathbf{5 7 . 3}$ \\
\hline 1995 & 4.7 & 5.0 & 3.4 & 3.7 & 7.1 & 6.9 & 14.4 & 25.1 \\
\hline 1996 & 3.8 & 4.1 & 2.3 & 2.6 & 6.0 & 6.1 & 66.5 & 59.7 \\
\hline 1997 & 4.4 & 4.2 & 2.6 & 2.7 & 6.5 & 5.4 & 57.8 & 122.5 \\
\hline 1998 & 6.2 & 6.3 & 4.4 & 5.0 & 8.9 & 7.6 & 9.4 & 16.0 \\
\hline 1999 & 4.4 & 4.9 & 2.7 & 3.5 & 6.2 & 6.4 & 42.8 & 58.4 \\
\hline 2000 & 3.5 & 3.9 & 1.8 & 2.2 & 5.6 & 5.9 & 2.7 & 29.1 \\
\hline 2001 & 5.0 & 5.2 & 3.2 & 3.5 & 7.0 & 6.8 & 42.3 & 43.6 \\
\hline 2002 & 5.5 & 5.8 & 4.0 & 4.4 & 7.5 & 7.2 & 153.0 & 117.0 \\
\hline 2003 & 5.5 & 5.8 & 3.8 & 4.2 & 7.7 & 7.4 & 31.6 & 36.5 \\
\hline 2004 & 5.5 & 5.8 & 3.6 & 3.9 & 7.7 & 7.4 & 77.4 & 66.9 \\
\hline 2005 & 5.3 & 5.8 & 3.9 & 4.1 & 7.3 & 7.5 & 33.6 & 49.9 \\
\hline 2006 & 5.1 & 5.2 & 3.8 & 3.9 & 6.8 & 7.0 & 24.2 & 25.1 \\
\hline 2007 & 5.1 & 5.5 & 3.5 & 4.0 & 7.2 & 7.4 & 32.2 & 12.3 \\
\hline 2008 & 4.1 & 4.5 & 2.5 & 2.9 & 6.2 & 6.1 & 20.7 & 22.2 \\
\hline 2009 & 5.0 & 6.1 & 3.1 & 4.1 & 7.1 & 7.6 & 39.4 & 13.0 \\
\hline 2010 & 3.9 & 4.1 & 2.0 & 2.7 & 6.0 & 6.1 & 13.3 & 8.5 \\
\hline $\begin{array}{c}1975- \\
2010\end{array}$ & 4.6 & 4.9 & 3.0 & 3.4 & 6.6 & 6.5 & 47.6 & 46.5 \\
\hline
\end{tabular}

Reconstructed data for Kaffiøyra-Heggodden station are marked in bold.

For the meaning of abbreviations see Table 1. 
Ny Ålesund. Table 3 presents all the reconstructed data for Kaffiøyra, together with the original measured ones, and the data from Ny Ålesund.

A comparison of mean seasonal air temperature parameters, as well as precipitation totals, presented in Table 1 (calculation from 18 summers) and Table 3 (calculated from all 36 summers), reveals slight changes. For example $\mathrm{T}_{\mathrm{i}}$ should be corrected from $4.8^{\circ} \mathrm{C}$ to $4.9^{\circ} \mathrm{C}$, and precipitation from $40.7 \mathrm{~mm}$ to $46.5 \mathrm{~mm}$. Continuous temperature records for Kaffiøyra using both methods of their reconstruction are presented in Figure 8. It is very well visible that the differences

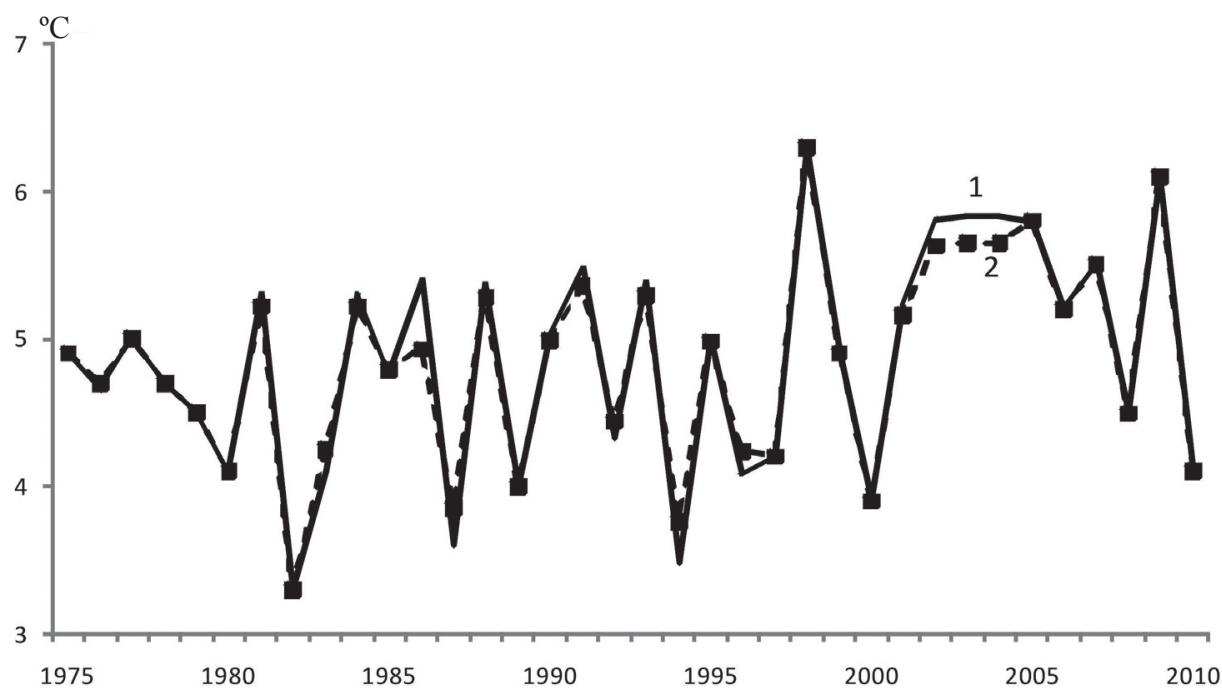

Figure 8. Reconstruction of mean seasonal ( $21^{\text {st }}$ July-31 $1^{\text {st }}$ August) air temperature in KaffiøyraHeggodden (KH) station using seasonal (1), and daily (2) values, 1975-2010

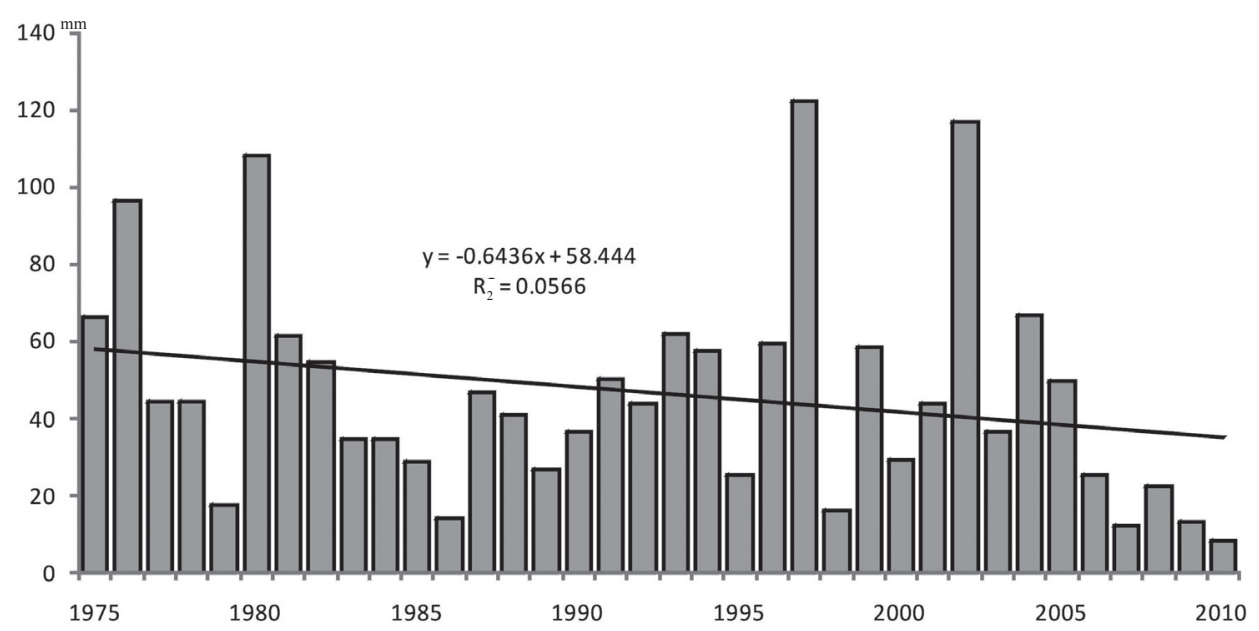

Figure 9. Reconstruction of seasonal ( $21^{\text {st }} \mathrm{July}-31^{\text {st }}$ August $)$ totals of precipitation in KaffiøyraHeggodden (KH) station, 1975-2010 
between the reconstructed values are very small. Only for a few years (e.g. 2003 and 2004) some small differences have been revealed. The continuous series of seasonal totals of precipitation for Kaffiøyra including both original and reconstructed data is presented in Figure 9. Having completed the series of both temperature ( $\mathrm{T}_{\max }$, $\mathrm{T}_{\mathrm{i}}$ and $\mathrm{T}_{\min }$ ) and precipitation, it is now possible to calculate trends (Figs 8 and 9). In the study period (1975-2010) an increase in air temperature occurred in all the presented parameters. However, a statistically significant increase with a rate of $0.23^{\circ} \mathrm{C} /$ decade was noted only for $\mathrm{T}_{\mathrm{i}}$. $\mathrm{T}_{\min }$ showed a slightly lower increase than $\mathrm{T}_{\max }$. On the other hand, precipitation totals in summer season in Kaffiøyra show a downward trend $(6.44 \mathrm{~mm} /$ decade $)$, which is not statistically significant.

\section{DISCUSSION AND FINAL REMARKS}

Changes in air temperature and precipitation presented here for Kaffiøyra for the period of 1975-2010 can be reliably compared with appropriate series from $\mathrm{Ny}$ Ålesund. $\mathrm{T}_{\mathrm{i}}$ in Ny Ålesund during this time shows a slightly lower rate of increase $\left(0.15^{\circ} \mathrm{C} /\right.$ decade $)$ than in Kaffiøyra $\left(0.23^{\circ} \mathrm{C} /\right.$ decade $)$. On the other hand, maximum and minimum temperatures rose in $\mathrm{Ny}$ Ålesund $\left(0.23\right.$ and $0.22^{\circ} \mathrm{C} /$ decade, respectively) with a greater rate than in Kaffiøyra $\left(0.19\right.$ and $0.20^{\circ} \mathrm{C} /$ decade, respectively). In $\mathrm{Ny}$ Alesund the precipitation decrease was slightly greater $(6.97 \mathrm{~mm} /$ decade $)$ than in Kaffiøyra ( $6.44 \mathrm{~mm} /$ decade). The trend in both places, however, is not statistically significant. In conclusion, one can say that in the north-west Spitsbergen, covering the areas from Kaffiøyra to Ny Ålesund, the rise in temperature in the study period was about $0.5^{\circ} \mathrm{C}$, while precipitation decreased by about $20 \mathrm{~mm}$. According to our calculations made for all mean monthly temperatures for Ny Ålesund (not shown), August was the month with the least increase in temperature (only $0.1^{\circ} \mathrm{C} /$ decade) in the period 1975-2010. A significantly higher increase in air temperature was observed in two other summer months, July and June $\left(0.3\right.$ and $0.4^{\circ} \mathrm{C} /$ decade, respectively). As a result, summer air temperature (June-August) during this time warmed by about $1.0^{\circ} \mathrm{C}$ and the rise was statistically significant. Changes in real summer temperatures are given here just for a better comparison with data from other Spitsbergen meteorological stations, for which this kind of data is easily available. In the central part of Spitsbergen, represented by Svalbard Lufthavn station, the air temperature increase was greater than in the north-western part by about $0.5^{\circ} \mathrm{C}$ (Nordli 2010). On the other hand, in Hornsund (south part of Spitsbergen) the temperature increase was equal to about $0.8^{\circ} \mathrm{C}$.

Precipitation changes in other parts of Spitsbergen are in accord with changes observed in north-western part, i.e. everywhere downward trends are common.

The analysis presented here shows that the existing number of meteorological observations for the Kaffiøyra region is enough to reliably reconstruct the missing data. At the present stage this was done for two main meteorological variables: 
temperature and precipitation. Successful reconstruction of this kind of data means that also reconstruction of other meteorological variables might be possible. Seasonal statistics presented air temperature and precipitation on the basis of not complete but more or less evenly distributed set of observations from the period 1975-2010 changed only slightly in comparison with statistics calculated for all the years of the study period (i.e. with gaps in series completed using reconstruction methods).

Air temperature parameters $\left(\mathrm{T}_{\mathrm{i}}, \mathrm{T}_{\max }\right.$ and $\left.\mathrm{T}_{\min }\right)$ for summer in Kaffiøyra in the study period (1975-2010) show upward trends, of which, however, only the one for $T_{i}$ is statistically significant. On the other hand, precipitation totals in the study period reveal a downward trend, but not statistically significant. Such thermalprecipitation behaviour in the study part of Spitsbergen in general terms is similar to those in other parts of Spitsbergen.

\section{ACKNOWLEDGMENTS}

The research in the present paper was supported by the Polish-Norwegian Fund as part of the project entitled 'Arctic Climate and Environment of the Nordic Seas and the Svalbard-Greenland Area' (AWAKE).

\section{REFERENCES}

Araźny A., 1999, Warunki meteorologiczne na Równinie Kaffiöyra (NW Spitsbergen) $w$ okresie 20.07-2.09.1998, (Meteorological conditions in the Kaffiöyra Plain (NW Spitsbergen) during the period 20.07-02.09.1998, Problemy Klimatologii Polarnej, 9, Gdynia, 103-116.

Araźny A., 2002, Warunki meteorologiczne na Równinie Kaffiöyra (NW Spitsbergen) w okresie 21 VII - 01 IX 1997 r., (Meteorological conditions in the Kaffiöyra Plain - (NW Spitsbergen - during the period 21.07-1.09.1997), Problemy Klimatologii Polarnej, 10, Toruń, 73-92.

Jankowska J., Kejna M., 2010, Warunki meteorologiczne na Równinie Kaffiøyra (NW Spitsbergen) w okresie 8.07-31.08.2009 r., (Meteorological conditions in the Kaffiöyra Plain - NW Spitsbergen - during the period 08.07-31.08.2009), [in:] XXX Sympozjum Polarne, Abstrakty, Łódź, 17-19.06. 2010, 33.

Kejna M., 2002, Warunki meteorologiczne na Kaffiöyrze (NW Spitsbergen) w okresie od 13 lipca do 9 września 1999 roku, (Meteorological conditions in the Kaffiörra - NW Spitsbergen - during the period 13.07-09.09.1999), Problemy Klimatologii Polarnej, 10, Toruń, 93-110.

Kejna M., Dzieniszewski M., 1993, Warunki meteorologiczne na Kaffiöyra (NW Spitsbergen) $w$ okresie 26.06-31.08.1985 r., (Meteorological conditions in the Kaffiöyra - NW Spitsbergen - during the period 26.06-31.08.1985), AUNC, Geografia XXIV, Torun, 43-54. 
Kejna M., Maszewski R., 2007, Warunki meteorologiczne na Równinie Kafföyra (NW Spitsbergen) w okresie od 5 lipca do 31 sierpnia 2006 roku, (Meteorological conditions in the Kaffiöyra Plain - NW Spitsbergen - during the period 05.07-31.08.2006), [in:] Przybylak R. et al. (eds.), Abiotyczne środowisko Spitsbergenu w latach 2005-2006 (Abiotic environment of Spitsbergen in 2005-2006), Zakład Klimatologii UMK, Toruń, 147-164.

Leszkiewicz J., 1977, Meteorological conditions in the northern part of Kaffiöyra Plain during the period from July 1 to August 31, 1975, AUNC, Geografia, XIII, 82, Toruń, 97-111.

Marciniak K., Przybylak R., 1983, Meteorological conditions in the Kaffiöyra (NW Spitsbergen) since $7^{\text {th }}$ July to $5^{\text {th }}$ September 1979, AUNC, Geografia XVIII, Torun, 113-123.

Marciniak K., Przybylak R., 1991, Warunki meteorologiczne na Równinie Kaffïyra (NW Spitsbergen) w okresie 5 VI -7 IX 1980 r., (Meteorological conditions in the Kaffiörra Plain - NW Spitsbergen - during the period 05.06-07.09.1980), AUNC, Geografia, XXII, Toruń, 97-107.

Marciniak K., Przybylak R., Kejna M., 1993, Dynamika warunków meteorologicznych na Równinie Kaffiöyra (NW Spitsbergen) w okresie 8.07-7.09 1989 r., (Dynamics of meteorological conditions in the Kaffiöyra Plain - NW Spitsbergen - during the period 8.07-07.09.1989), Wyniki badań VIII Toruńskiej Wyprawy Polarnej „Spitsbergen’ 89", 31-46.

Maszewski R., Wyszyński P., 2008, Warunki meteorologiczne na Kaffioyrze (NW Spitsbergen) w okresie od 5 lipca do 31 sierpnia 2007, (Meteorological conditions in the Kaffiöyra - NW Spitsbergen - during the period 05.07-31.08.2007), [in:] Kowalska A. (ed.), IV Międzynarodowy Rok Polarny, skrypt XXXII Międzynarodowe Sympozjum Polarne, Wrocław, 54-58.

Nordli Ø., 2010, The Svalbard Airport temperature series, Bulletin of Geography - Physical Geography Series, 3, 5-25.

Przybylak R., 2002, Variability of air temperature and atmospheric precipitation in the Arctic, Atmospheric and Oceanographic Sciences Library 25, Kluwer Academic Publishers: Dordrecht/Boston/London, p. 330.

Przybylak R., 2003, The Climate of the Arctic, Atmospheric and Oceanographic Sciences Library, 26, Kluwer Academic Publishers, Dordrecht/Boston/London, p. 288.

Przybylak R., 2007, Recent air-temperature changes in the Arctic, Annals of Glaciology, 46, 316-324.

Przybylak R., Araźny A., 2006, Climatic conditions of the north-western part of Oscar II Land (Spitsbergen) in the period between 1975 and 2000, Polish Polar Research, 27, 2, 133-152.

Przybylak R., Araźny A., 2007, Warunki meteorologiczne na Równinie Kafföyra (NW Spitsbergen) w okresie od 13 lipca do 20 września 2005 r., (Meteorological conditions in the Kaffiörra Plain - NW Spitsbergen - during the period 13.07-20.09.2005), [in:] Przybylak R. et al. (eds.), Abiotyczne środowisko Spitsbergenu w latach 2005-2006 (Abiotic environment of Spitsbergen in 2005-2006), Zakład Klimatologii UMK, Toruń, 33-50.

Przybylak R., Szczeblewska E., 2002, Warunki meteorologiczne na Równinie Kaffiöyra (NW Spitsbergen) w okresie od 3 VII do 31 VIII 2000 r., (Meteorological conditions in the Kaffiöyra Plain - NW Spitsbergen - during the period 03.07-31.08.2000), Problemy Klimatologii Polarnej, 10, 111-137. 
Wójcik G., 1982, Meteorological conditions at the Kaffïyra Plain - Spitsbergen from $21^{\text {st }}$ July to $28^{\text {th }}$ August 1977, AUNC, Geografia XVI, Toruń, 151-166.

Wójcik G., Marciniak K., 1983, Meteorological conditions in the Kaffiöyra Plain (NW Spitsbergen) since $21^{\text {st }}$ July to $7^{\text {th }}$ September 1978, AUNC, Geografia XVIII, Torun, 99-111.

Wójcik G., Kejna M., Marciniak K., Przybylak R., ViziZ., 1997, Obserwacjemeteorologiczne na Ziemi Oskara II (Spitsbergen) i w Oazie Bungera (Antarktyda), Sezony letnie 1975, 1977, 1978, 1979, 1980, 1982, 1985, 1989 (Meteorogical Observation in Oscar II Land (Spitsbergen) and Bunger Oasis (Antarctic) in the summer seosons 1975, 1977, 1978, 1979, 1980, 1982, 1985, 1989), Oficyna Wydawnicza „Turpress”, Toruń, pp. 412.

Wójcik G., Marciniak K., Przybylak R., 1991, Mezoklimatyczne i topoklimatyczne jednostki w rejonie Kaffiöyry (NW Spitsbergen), (Mezo- and topoclimatic units in the Kaffiöyra - NW Spitsbergen [in:] Wspótczesne badania topoklimatyczne, Pr. Inst. Geogr., ser. A, Geografia fizyczna, V, Wrocław, 323-342.

Wójcik G., Przybylak R., 1991, Warunki meteorologiczne na Równinie Kaffiöyra (NW Spitsbergen) w okresie 14 lipca - 9 września 1982 r., (Meteorological conditions in the Kaffioyra Plain - NW Spitsbergen - during the period 14.07-09.09.1982), AUNC, Geografia XXII, Toruń, 109-124. 